\title{
Modification of Plant Architecture in 'Crimson Giant' Easter Cactus with Benzyladenine
}

\author{
Thomas H. Boyle \\ Department of Plant and Soil Sciences, French Hall, University of Massachusetts, Amherst, \\ MA 01003 \\ Additional index words. BA, branching, flowering pot plant, ornamental plant, Rhipsalidopsis gaertneri
}

\begin{abstract}
Investigations were performed to determine the effects of timing of application and concentration of BA on the vegetative growth of Easter cactus [Rhipsalidopsis gaertneri (Regel) Moran 'Crimson Giant']. BA was applied to rooted phylloclades at 27,37 , and/or 47 days after propagation (DAP) at 200 to $1000 \mathrm{mg} \cdot \mathrm{liter}^{-1}$. At 80 DAP, the number and cumulative length of secondary $\left(2^{\circ}\right)$ phylloclades (those developing from the rooted phylloclade) of BAtreated plants exceeded those of the controls. Number and cumulative length of $2^{\circ}$ phylloclades increased linearly with increasing BA concentration. At 316 DAP, there were no differences between BA-treated plants and controls in numbers of $2^{\circ}$ and apical (terminal) phylloclades. BA also was applied to plants at either 95 or 187 DAP. Treatments included 10, 50, 100, and $200 \mathrm{mg} \mathrm{BA} /$ liter and an unsprayed control. Number of new phylloclades (those developing after treatments) and percentage of old phylloclades with new phylloclades increased linearly in response to increasing BA concentration. Relative to the controls, one application of $\mathrm{BA}$ at 50,100 , or $200 \mathrm{mg} \cdot \operatorname{liter}{ }^{-1}$ resulted in a $\approx 50 \%$ to $400 \%$ increase in total dry weight of new phylloclades accompanied by a $\approx 4 \%$ to $30 \%$ decrease in total dry weight of old phylloclades. Branching of mature plants, i.e., with three to five tiers of phylloclades, was significantly affected by timing of application and concentration of BA. BA may be useful for modifying plant architecture of Easter cactus to increase flowering and product marketability. Chemical name used: $N$ - (phenylmethyl) $-1 H$ - purine-6-amine[benzyladenine (BA)].
\end{abstract}

Easter cactus [currently Rhipsalidopsis gaertneri (Regel) Moran (Liberty Hyde Bailey Hortorium, 1976), but proposed by Barthlott (1987) as Hatiora gaertneri (Regel) Barthlott] is an epiphytic species of the Cactaceae exhibiting a determinate growth pattern and producing a series of leafless, flattened phylloclades. Flowers are produced primarily on apical (terminal) phylloclades (Boyle et al., 1988; Wilkins and Rünger, 1985). For a plant composed of $n$ phylloclades, the number of flower buds per plant can thus be considered a function of three components: 1) percentage of $n$ phylloclades that are apical phylloclades, 2) percentage of apical phylloclades flowering, and 3) number of flower buds per flowering apical phylloclade. The latter two components depend on the maturity of apical phylloclades and environmental conditions before and subsequent to floral induction (Boyle, 1991; Boyle et al., 1988; Peters and Rünger, 1971). The first component depends on the degree of branching. Plants exhibiting more branching would be expected to produce more apical phylloclades and, consequently, more flowers than those less branched. Therefore, enhancement of branching may be an effective method for increasing flowering in Easter cactus.

In the related epiphyte Schlumbergera truncata (Haw.) Moran, branching is increased by spray applications of the cytokinin BA (Heins et al., 1981; Ho et al., 1985; Yonemura, 1979). Cytokinins have also been shown to promote branching in other Cactaceae species, including Chamaecereus silvestri (Speg.) Britt. \& Rose (Sanderson et al., 1986), Hylocereus trigonus (Haw.) Saff. (Shimomura and Fujikara, 1980), Mammillaria elongata DC. (Sanderson et al., 1986), and Opuntia basilaris Englem. \& Bigel. (White et al., 1978). Mauseth (1976) and Mauseth and Halperin (1975) reported that BA promoted phylloclade

Received for publication 7 June 1991. Accepted for publication 10 Feb. 1992 Publication no. 3018 of the Massachusetts Agr. Exp. Sta. I wish to acknowledge partial support of this investigation by a grant awarded by the American Floral Endowment. The cost of publishing this paper was defrayed in part by the payment of page charges. Under postal regulations, this paper therefore must be hereby marked advertisement solely to indicate this fact. initiation and growth when quiescent buds of Opuntia polyacantha Haw. were cultured in vitro.

In $S$. truncata, the response to BA depends on the phase of plant development. BA increased the number of apical phylloclades on vegetative plants but increased the number of flowers on reproductive plants (Heins et al., 1981; Rünger, 1984; Yonemura, 1979). When 'Crimson Giant' Easter cactus was grown under conditions promoting flowering, application of $100 \mathrm{mg}$ $\mathrm{BA} /$ liter more than doubled the number of flowers (Boyle et al., 1988). I found no reports, however, on the vegetative responses of Easter cactus to BA. This investigation was initiated to determine the responses of vegetative 'Crimson Giant' Easter cactus to timing of application and concentration of BA.

\section{Materials and Methods}

General procedures. Plants were propagated and grown in glasshouses at the Univ. of Massachusetts, Amherst (lat. $42^{\circ} 22.5^{\prime} \mathrm{N}$ ). Thermostat set points were $18 / 20 \mathrm{C}$ (heat/vent). Actual air temperatures were monitored using a thermograph with a bimetallic-strip sensor (Cole-Palmer Instrument, Chicago) or a LI-1000 datalogger (LI-COR, Lincoln, Neb.) equipped with a LI-COR LI-1000-16 thermistor. Photosynthetic photon flux (PPF) was monitored with a LI-1000 datalogger using a LICOR LI-190SA quantum sensor. Air temperatures ranged from 16 to $39 \mathrm{C}$ during the three experiments. BA treatments were applied near midday (1200 HR) in all experiments; temperature, $\mathrm{PPF}$, and photoperiod on the dates of BA application are provided in Table 1. Plants were fertilized weekly with $20 \mathrm{~N}-4.3 \mathrm{P}-$ $16.6 \mathrm{~K}\left(12 \% \mathrm{NO}_{3}-\mathrm{N}, 8 \% \mathrm{NH}_{4}-\mathrm{N}\right)$ at $200 \mathrm{mg} \mathrm{N} /$ liter. Fertilization began after phylloclades were rooted and continued throughout the experiments.

$B A$ applications to rooted phylloclades (Expt. 1). Whole phylloclades were propagated in 72-cell plastic flats (eight packs

Abbreviations: DAP, days after propagation; ND, natural daylengths; PWR, phylloclade weight ratio; $1^{\circ}$, primary; $2^{\circ}$, secondary, $3^{\circ}$, tertiary. 
Table 1. Glasshouse environmental conditions recorded on dates of BA application.

\begin{tabular}{|c|c|c|c|c|c|}
\hline \multirow[b]{2}{*}{ Experiment } & \multirow{2}{*}{$\begin{array}{l}\text { Date of BA } \\
\text { application }\end{array}$} & \multirow{2}{*}{$\begin{array}{l}\text { Air temp } \\
\left({ }^{\circ} \mathrm{C}\right)^{z}\end{array}$} & \multirow{2}{*}{$\begin{array}{c}\text { PPF } \\
\left(\mu \mathrm{mol} \cdot \mathrm{m}^{-2} \cdot \mathrm{s}^{-1}\right)^{z}\end{array}$} & \multicolumn{2}{|c|}{$\begin{array}{c}\text { Natural } \\
\text { photoperiod }\end{array}$} \\
\hline & & & & $\mathrm{h}$ & $\min$ \\
\hline 1 & $\begin{array}{r}24 \text { Dec. } 1988 \\
3 \text { Jan. } 1989 \\
13 \text { Jan. } 1989\end{array}$ & $\begin{array}{l}17.8 \pm 0.2 \\
18.2 \pm 0.4 \\
19.1 \pm 0.4\end{array}$ & $\begin{array}{l}344 \pm 115 \\
366 \pm 111 \\
477 \pm 98\end{array}$ & $\begin{array}{l}9 \\
9 \\
9\end{array}$ & $\begin{array}{r}7 \\
13 \\
24\end{array}$ \\
\hline 2 & 24 July 1990 & $26.2 \pm 1.4$ & $495 \pm 62$ & 14 & 44 \\
\hline 3 & 1 Oct. 198 & $21.3 \pm 1.3$ & $599 \pm 127$ & 11 & 45 \\
\hline
\end{tabular}

${ }^{\mathrm{z}}$ Actual glasshouse air temperatures and PPF were collected by a datalogger configured with a sampling interval of $60 \mathrm{sec}$ and recording mean values at 1 -h intervals. Data are averages of hourly means for 1000 to $1359 \mathrm{HR} \pm 1 \mathrm{SE}$.

'Duration of daylight (interval between sunrise and sunset) at $42^{\circ} \mathrm{N}$ lat. Data from List (1951).

per flat and nine cells per pack) on 27 Nov. using one phylloclade per $50-\mathrm{cm}^{3}$ cell. A commercial soilless mix (Fafard Mix No. 2, Conrad Fafard, Springfield, Mass.) was used as the propagation medium. Natural daylengths (ND) were maintained for the duration of the experiment.

In a preliminary experiment, single- or multiple-spray applications of BA at $\leq 100 \mathrm{mg} \cdot$ liter $^{-1}$ were ineffective in increasing the number of $2^{\circ}$ phylloclades on newly rooted phylloclades (data not presented). Consequently, Expt. 1 was performed to examine the influence of BA at concentrations $\geq 200 \mathrm{mg} \cdot \mathrm{liter}^{-1}$. Treatments included an unsprayed control and BA at 200,400, 600,800 , and $1000 \mathrm{mg} \cdot$ liter $^{-1}$ in one, two, or three applications (see Table 2). Solutions of BA (Sigma, St. Louis) contained 1 $\mathrm{ml}$ Tween 20 (polyoxyethylene sorbitan monolaurate)/liter as a surfactant, and they were applied with a pressurized hand sprayer at a rate of $\approx 3 \mathrm{ml} /$ plant. The initial treatment was applied on 24 Dec. (27 DAP) when > 98\% of phylloclades were rooted; the second and third dates of application were 3 Jan. (37 DAP) and 13 Jan. (47 DAP), respectively. The experiment was a completely randomized design with three replications (packs) per treatment.

Data on the number and length of secondary $\left(2^{\circ}\right)$ phylloclades [those developing from the rooted primary $\left(1^{\circ}\right)$ phylloclade] were collected on 15 Feb. (80 DAP). Length data were expressed as the cumulative length of $2^{\circ}$ phylloclades ( $\geq 1 \mathrm{~mm}$ long) on each rooted phylloclade.

In late April, plants were potted individually into $520-\mathrm{cm}^{3}$ (10-cm diameter) plastic pots using Fafard Mix No. 2 as the growing medium. There were 14 pots per treatment, and pots were completely randomized on the greenhouse bench. The number of $2^{\circ}$ phylloclades, tertiary $\left(3^{\circ}\right)$ phylloclades (those developing from the $2^{\circ}$ phylloclades), apical phylloclades [terminal $2^{\circ}, 3^{\circ}$, and quaternary $\left(4^{\circ}\right)$ phylloclades], and phylloclades per plant were recorded on 9 Oct. (316 DAP).

BA applications to 3-month-old plants (Expt. 2). Whole phylloclades were propagated in 72-cell plastic trays on 19 Apr., using one phylloclade per $35-\mathrm{cm}^{3}$ cell. On 15 July, plants were transplanted individually into $520-\mathrm{cm}^{3}$ plastic pots using Fafard No. 2 growing medium. Plants were grown under ND from propagation until harvest.

Treatments were applied on 23 July (95 DAP) to plants with two mature tiers of phylloclades. Before spray applications, apical phylloclades were marked with indelible ink to distinguish "old" phylloclades (those present on 23 July) from "new" phylloclades (those developing after 23 July). Treatments included BA at 10, 50, 100, and $200 \mathrm{mg} \cdot \operatorname{liter}^{-1}$ and an unsprayed
Table 2. Influence of BA concentration and time of application on number and cumulative length of $2^{\circ}$ phylloclades in 'Crimson Giant' Easter cactus at 80 DAP.

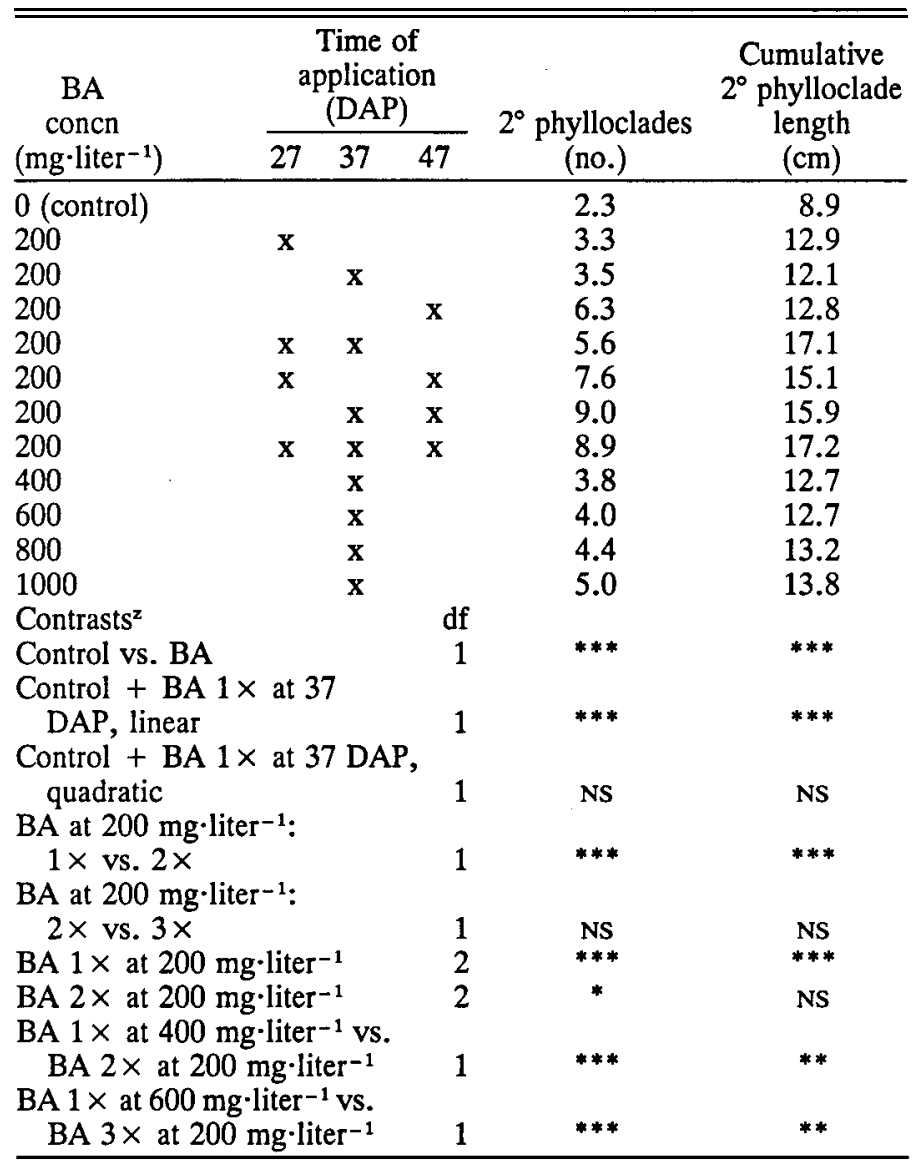

$\mathrm{NS}, *, * *, * * * \mathrm{~F}$ test of contrast not significant or significant at $0.05 \geq \alpha$ $>0.01,0.01 \geq \alpha>0.001$, or $\alpha \leq 0.001$, respectively.

control. BA solutions contained $1 \mathrm{ml}$ Tween 20/liter as a surfactant and were applied with a pressurized hand sprayer at a rate of $\approx 10 \mathrm{ml} / \mathrm{plant}$. The experiment was a completely randomized design with eight pots per treatment.

The number of old and new phylloclades on each plant was recorded 60 days after treatments. Old and new phylloclades were harvested from each plant and dried in a forced-air oven at $60 \mathrm{C}$ to constant weight. Phylloclade weight ratio (PWR) was calculated by dividing the new phylloclade dry weight (grams) by the old phylloclade dry weight (grams). The variable PWR was constructed to illustrate the relative changes in dry weight partitioning between new and old phylloclades in response to BA treatments.

BA applications to 6-month-old plants (Expt. 3). Whole phylloclades were propagated in 72-cell plastic trays on 27 Mar., using one phylloclade per $35-\mathrm{cm}^{3}$ cell. In early June, rooted phylloclades were transplanted individually into $520-\mathrm{cm}^{3}$ plastic pots using a commercial soilless mix (Ball Growing Mix 1, Geo. J. Ball, Chicago). Plants received ND from propagation until 2 Sept. [13 h, $7 \mathrm{~min} \mathrm{ND}$ at lat. $42^{\circ} \mathrm{N}$ (List, 1951)]. To promote vegetative growth, long days (LD) were provided from 2 Sept. until harvest by supplementing ND with incandescent irradiation [an instantaneous value of $\approx 3 \mu \mathrm{mol} \cdot \mathrm{m}^{-2} \cdot \mathrm{s}^{-1}(400$ to $700 \mathrm{~nm})$ at plant canopy height] from 1600 to $2200 \mathrm{HR}$.

Plants consisting of three to four tiers of phylloclades were pruned on 17 Sept. to three tiers. Apical phylloclades were marked (as described in Expt. 2) before spray applications. Plants 


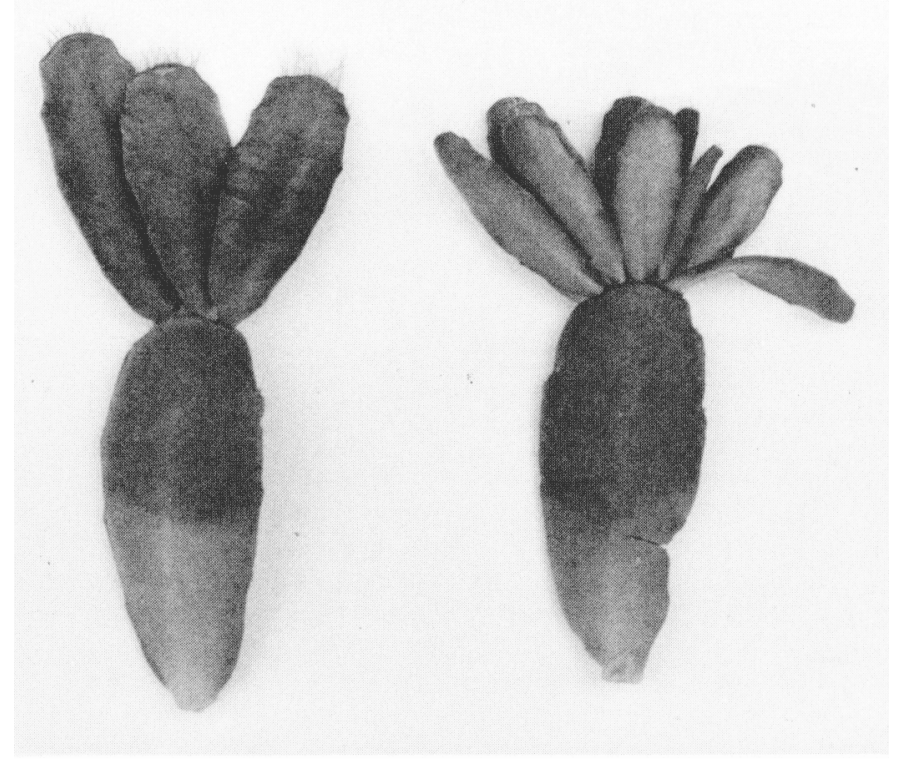

Fig. 1. Effect of BA on development of $2^{\circ}$ phylloclades on rooted $1^{\circ}$ phyllocades of 'Crimson Giant' Easter cactus. Plant on the left was untreated (control). Plant on the right was sprayed with $200 \mathrm{mg} \mathrm{BA} /$ liter at 37 and 47 DAP. Photograph was taken at 80 DAP. Roots were removed from plants for photographic presentation.

were sprayed on 1 Oct. (187 DAP) and included BA at 10, 50, 100 , and $200 \mathrm{mg} \cdot \mathrm{liter}^{-1}$, and an unsprayed control. BA solutions were mixed as described in Expt. 2 and applied at a rate of $\approx 15 \mathrm{ml} / \mathrm{plant}$. The experiment was a completely randomized design with seven pots per treatment.

Plants were harvested 60 days after treatment. Data were collected on the number and dry weight of old and new phylloclades. PWR was calculated as described in Expt. 2.

Statistical analyses. One dependent variable [number of $2^{\circ}$ phylloclades at 80 DAP (Expt. 1)] demonstrated variance heterogeneity and was transformed $\left[\log _{10}(\mathrm{x}+1)\right]$ before statistical analysis (Gomez and Gomez, 1984). All data were analyzed by the general linear model (GLM) procedure (SAS Institute, 1985). A hierarchical classification was used to separate treatment effects, experimental error (variation among packs within treatments), and sampling error (variation among plants within packs) for Expt. 1 data collected at 80 DAP. Coefficients of linear correlation $(r)$ were calculated to determine relationships between variables recorded at 80 and/or 316 DAP in Expt. 1. For Expts. 2 and 3, coefficients for linear and quadratic terms were calculated using the procedure of Gomez and Gomez (1984) for unequally spaced treatments.

\section{Results and Discussion}

Experiment 1. Secondary phylloclades were not observed at 27 DAP but were present on $\approx 5 \%$ and $\approx 25 \%$ of rooted phylloclades at 37 and 47 DAP, respectively. Application of BA increased the number and cumulative length of $2^{\circ}$ phylloclades at 80 DAP compared to unsprayed controls (Table 2, Fig. 1). The number and cumulative length of $2^{\circ}$ phylloclades increased linearly with increasing BA concentration. At $200 \mathrm{mg} \cdot \mathrm{liter}^{-1}$, two applications increased the number and cumulative length of $2^{\circ}$ phylloclades more than one application, but there were no significant differences between two and three applications. When BA was applied once at $200 \mathrm{mg} \cdot \mathrm{liter}^{-1}$, an application at 47 DAP was more effective than one at 27 or 37 DAP. When BA was applied twice at $200 \mathrm{mg} \cdot$ liter $^{-1}$, applications at 37 and 47 DAP resulted in more $2^{\circ}$ phylloclades than applications at 27 and 37 DAP, but cumulative length of $2^{\circ}$ phylloclades was not affected by timing of application. Multiple applications of BA at $200 \mathrm{mg} \cdot$ liter $^{-1}$ were more effective than a single application of $\mathrm{BA}$ at $>200 \mathrm{mg} \cdot \mathrm{liter}^{-1}$

There were significant differences among treatments for number of $2^{\circ}$ phylloclades, apical phylloclades, and of phylloclades per plant at 316 DAP (Table 3). There were, however, no differences between BA-treated plants and controls in the number of $2^{\circ}$ and apical phylloclades. Generally, BA treatments reduced the number of $3^{\circ}$ phylloclades and of phylloclades per plant. These results indicate that BA applications to rooted phylloclades of 'Crimson Giant' resulted in a temporary increase in

Table 3. Effect of BA concentration and time of application on vegetative growth of 'Crimson Giant' Easter cactus at 316 DAP.

\begin{tabular}{|c|c|c|c|c|c|c|c|}
\hline \multirow{2}{*}{$\begin{array}{c}\mathrm{BA} \\
\text { concn } \\
\left(\mathrm{mg} \cdot \text { liter }^{-1}\right) \\
\end{array}$} & \multicolumn{3}{|c|}{$\begin{array}{l}\text { Time of } \\
\text { application } \\
\text { (DAP) }\end{array}$} & \multirow{2}{*}{$\begin{array}{c}2^{\circ} \text { phylloclades } \\
\text { (no.) }\end{array}$} & \multirow{2}{*}{$\begin{array}{c}3^{\circ} \text { phylloclades } \\
\text { (no.) }\end{array}$} & \multirow{2}{*}{$\begin{array}{c}\text { Apical phylloclades } \\
\text { (no.) }\end{array}$} & \multirow{2}{*}{$\begin{array}{l}\text { Phylloclades } \\
\text { per plant }\end{array}$} \\
\hline & 27 & 37 & 47 & & & & \\
\hline 0 (control) & & & & 8.7 & 32.0 & 44.1 & 69.1 \\
\hline 200 & $\mathbf{x}$ & & & 7.8 & 23.8 & 29.8 & 45.3 \\
\hline 200 & & $\mathbf{X}$ & & 7.9 & 26.6 & 36.2 & 56.8 \\
\hline 200 & & & $\mathbf{x}$ & 9.2 & 27.0 & 35.4 & 52.5 \\
\hline 200 & $\mathbf{x}$ & $\mathbf{x}$ & & 8.5 & 24.7 & 41.5 & 61.8 \\
\hline 200 & $\mathbf{x}$ & & $\mathbf{x}$ & 9.0 & 26.7 & 46.2 & 74.3 \\
\hline 200 & & $\mathbf{x}$ & $\mathbf{x}$ & 9.6 & 27.0 & 43.1 & 65.9 \\
\hline 200 & $\mathbf{x}$ & $\mathbf{x}$ & $\mathbf{x}$ & 10.1 & 27.8 & 41.3 & 67.0 \\
\hline 400 & & $\mathbf{x}$ & & 8.0 & 25.3 & 35.2 & 54.5 \\
\hline 600 & & $\mathbf{x}$ & & 7.8 & 29.8 & 42.7 & 61.9 \\
\hline 800 & & $\mathbf{x}$ & & 8.6 & 31.7 & 40.4 & 58.5 \\
\hline 1000 & & $\mathbf{x}$ & & 7.5 & 24.3 & 37.8 & 57.1 \\
\hline Significance & & $\mathrm{df}$ & & & & & \\
\hline Treatments & & 11 & & $* *$ & NS & $* *$ & $* * *$ \\
\hline Control vs. BA & & 1 & & NS & $*$ & NS & $*$ \\
\hline
\end{tabular}

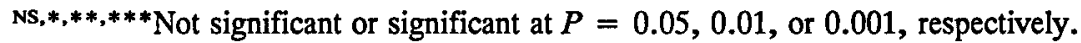


Table 4. Coefficients of linear correlation $(r)$ among numbers of $2^{\circ}$ phylloclades, $3^{\circ}$ phylloclades, apical phylloclades, and phylloclades per plant for 'Crimson Giant' Easter cactus. Number of $2^{\circ}$ phylloclades recorded at 80 and 316 DAP; all other data collected at 316 DAP.

\begin{tabular}{|c|c|c|}
\hline Correlation & $r$ & $P^{2}$ \\
\hline \multicolumn{3}{|l|}{ No. $2^{\circ}$ phylloclades at 80 DAP with: } \\
\hline No. $2^{\circ}$ phylloclades at 316 DAP & 0.79 & 0.002 \\
\hline No. $3^{\circ}$ phylloclades & -0.16 & 0.609 \\
\hline No. apical phylloclades & 0.40 & 0.202 \\
\hline No. phylloclades/plant & 0.46 & 0.136 \\
\hline \multicolumn{3}{|l|}{ No. $2^{\circ}$ phylloclades at 316 DAP with: } \\
\hline No. $3^{\circ}$ phylloclades & 0.27 & 0.393 \\
\hline No. apical phylloclades & 0.45 & 0.139 \\
\hline No. phylloclades/plant & 0.53 & 0.075 \\
\hline \multicolumn{3}{|l|}{ No. $3^{\circ}$ phylloclades with: } \\
\hline No. apical phylloclades & 0.54 & 0.070 \\
\hline No. phylloclades/plant & 0.44 & 0.149 \\
\hline \multicolumn{3}{|l|}{ No. apical phylloclades with: } \\
\hline No. phylloclades/plant & 0.96 & $<0.001$ \\
\hline
\end{tabular}

the number of $2^{\circ}$ phylloclades but decreased subsequent vegetative growth.

The number of $2^{\circ}$ phylloclades at 80 DAP was significantly correlated with the number of $2^{\circ}$ phylloclades at 316 DAP, but was not correlated with the number of $3^{\circ}$ phylloclades, apical phylloclades, or phylloclades per plant at 316 DAP (Table 4). The number of $2^{\circ}$ phylloclades at 316 DAP was not significantly correlated with the number of $3^{\circ}$ phylloclades, apical phylloclades, or phylloclades per plant, nor was the number of $3^{\circ}$ phylloclades correlated with the number of apical phylloclades or phylloclades per plant. A highly significant positive correlation was exhibited between number of apical phylloclades and phylloclades per plant.

Cytokinins promote branching apparently by increasing the translocation of assimilates from other plant parts to meristematic regions (Salisbury and Ross, 1978). BA may have reduced the number of $3^{\circ}$ phylloclades and total phylloclades per plant at 316 DAP by altering the normal pattern of assimilate distribution. During the early stage of expansion, leaves depend on assimilates imported from other plant organs; leaves become net assimilate exporters about the time that laminae have attained half the maximum area (Milthorpe and Moorby, 1979). A similar pattern of assimilate import/export would be expected during phylloclade growth in Rhipsalidopsis. The simultaneous development of several vegetative sinks (immature $2^{\circ}$ phylloclades) following BA application(s) probably increased the translocation of assimilates from source tissues $\left(1^{\circ}\right.$ phylloclades and/or roots). In the controls, initiation of $2^{\circ}$ phylloclades occurred over an extended period rather than concurrently [compare number of $2^{\circ}$ phylloclades at 80 and 316 DAP (Tables 2 and 3)]. Staggering the initiation of $2^{\circ}$ phylloclades may optimize the distribution of assimilates when the plant has limited stored carbohydrates and a smaller photosynthetic apparatus.

Experiment 2. The number of new phylloclades and percentage of old apical phylloclades with new phylloclades exhibited positive linear responses to BA concentration, whereas the unit dry weight of new phylloclades decreased linearly as BA concentration increased (Table 5). Total dry weight of new phylloclades was maximal following application of $100 \mathrm{mg} \mathrm{BA} / \mathrm{liter}$. Total and unit dry weight of old phylloclades was inversely related to BA concentration. However, the total shoot dry weight was unaffected by BA concentration. Relative to the unsprayed controls, the PWR displayed a sharp rise in response to 10 $\mathrm{mg} \cdot$ liter $^{-1} \mathrm{BA}$, and moderate but consistently positive gains in the PWR were obtained as BA concentration increased from 50 to $200 \mathrm{mg} \cdot$ liter $^{-1}$ (Fig. 2).

Experiment 3. Total dry weight of new phylloclades, number of new phylloclades, and total shoot dry weight increased linearly in response to increasing BA concentration (Table 6). A positive linear response to BA concentration was also shown for the percentage of old apical phylloclades with new phylloclades and the number of new phylloclades per old apical phylloclade. Increasing the BA concentration resulted in a linear decrease in the total and unit dry weight of old phylloclades. The PWR increased nearly 6-fold as BA concentration increased from 0 to $50 \mathrm{mg} \cdot$ liter $^{-1}$ but increasing the BA concentration from 50 to $200 \mathrm{mg} \cdot$ liter $^{-1}$ did not result in additional increases in the PWR (Fig. 2).

Branching of mature 'Crimson Giant' plants, i.e., those with three to five tiers of phylloclades, was significantly affected by timing of application and concentration of BA. Differences in plant sensitivity were detectable within a 10-day interval [compare one application of $200 \mathrm{mg} \cdot \mathrm{liter}^{-1} \mathrm{BA}$ at either 37 or 47 DAP (Table 2)]. When BA was applied at 37 DAP, the number of $2^{\circ}$ phylloclades increased $117 \%$ as BA concentration increased from 0 to $1000 \mathrm{mg} \cdot \operatorname{liter}^{-1}$ (Table 2). In contrast, the number of new phylloclades per plant increased $309 \%$ to $442 \%$ as BA concentration increased from 0 to $200 \mathrm{mg} \cdot \mathrm{liter}^{-1}$ when BA was applied at 95 or 187 DAP (Tables 5 and 6). BA concentrations ranging from 50 to $200 \mathrm{mg} \cdot \operatorname{liter}^{-1}$ have been re-

Table 5. Influence of BA concentration on vegetative growth of 3-month-old 'Crimson Giant' Easter cactus (Expt. 2).

\begin{tabular}{|c|c|c|c|c|c|c|c|c|}
\hline \multirow[b]{2}{*}{$\begin{array}{l}\text { BA } \\
\text { concn } \\
\left(\mathrm{mg} \cdot \text { liter }^{-1}\right)\end{array}$} & \multicolumn{3}{|c|}{ New phylloclades } & \multicolumn{3}{|c|}{ Old phylloclades } & \multirow{2}{*}{$\begin{array}{l}\text { Old apical } \\
\text { phylloclades } \\
\text { with new } \\
\text { phylloclades } \\
(\%)\end{array}$} & \multirow[b]{2}{*}{$\begin{array}{c}\text { Total shoot } \\
\text { dry wt } \\
\text { (g) }\end{array}$} \\
\hline & No./plant & $\begin{array}{c}\text { Total } \\
\text { dry wt } \\
\text { (g) }\end{array}$ & $\begin{array}{c}\text { Unit } \\
\text { dry wt } \\
\text { (g) }\end{array}$ & No./plant & $\begin{array}{c}\text { Total } \\
\text { dry wt } \\
(\mathrm{g}) \\
\end{array}$ & $\begin{array}{c}\text { Unit } \\
\text { dry wt } \\
\text { (g) }\end{array}$ & & \\
\hline 0 & 11 & 1.03 & 0.10 & 9 & 1.97 & 0.24 & 65 & 3.00 \\
\hline 10 & 13 & 1.51 & 0.12 & 9 & 2.02 & 0.24 & 92 & 3.53 \\
\hline 50 & 25 & 1.60 & 0.06 & 9 & 1.90 & 0.20 & 92 & 3.49 \\
\hline 100 & 33 & 1.72 & 0.05 & 9 & 1.85 & 0.21 & 93 & 3.57 \\
\hline 200 & 45 & 1.52 & 0.03 & 8 & 1.41 & 0.17 & 95 & 2.92 \\
\hline \multicolumn{9}{|l|}{ Significance } \\
\hline Linear & $* * *$ & NS & $* * *$ & NS & $* *$ & $* * *$ & * & NS \\
\hline Quadratic & * & ** & $* *$ & NS & NS & NS & NS & NS \\
\hline
\end{tabular}

NS,*,*****Not significant or significant at $P=0.05,0.01$, or 0.001 , respectively. 
Table 6. Effect of BA concentration on vegetative growth of 6-month-old 'Crimson Giant' Easter cactus (Expt. 3).

\begin{tabular}{|c|c|c|c|c|c|c|c|c|c|}
\hline \multirow[b]{2}{*}{$\begin{array}{l}\text { BA } \\
\text { concn } \\
\left(\mathrm{mg} \cdot \operatorname{liter}^{-1}\right)\end{array}$} & \multicolumn{3}{|c|}{ New phylloclades } & \multicolumn{3}{|c|}{ Old phylloclades } & \multirow{2}{*}{$\begin{array}{l}\text { Old apical } \\
\text { phylloclades } \\
\text { with new } \\
\text { phylloclades } \\
(\%)\end{array}$} & \multirow{2}{*}{$\begin{array}{c}\text { New } \\
\text { phylloclades/ } \\
\text { old apical } \\
\text { phylloclade } \\
\text { (no.) }\end{array}$} & \multirow[b]{2}{*}{$\begin{array}{c}\text { Total shoo } \\
\text { dry wt } \\
\text { (g) }\end{array}$} \\
\hline & No./plant & $\begin{array}{l}\text { Total } \\
\text { dry wt } \\
\text { (g) }\end{array}$ & $\begin{array}{c}\text { Unit } \\
\text { dry wt } \\
\text { (g) }\end{array}$ & No./plant & $\begin{array}{c}\text { Total } \\
\text { dry wt } \\
(\mathrm{g})\end{array}$ & $\begin{array}{c}\text { Unit } \\
\text { dry wt } \\
\text { (g) }\end{array}$ & & & \\
\hline 0 & 12 & 0.52 & 0.04 & 29 & 7.46 & 0.26 & 35 & 1.6 & 7.97 \\
\hline 10 & 14 & 0.82 & 0.06 & 28 & 6.90 & 0.25 & 50 & 1.3 & 7.72 \\
\hline 50 & 49 & 2.31 & 0.05 & 29 & 5.34 & 0.19 & 78 & 3.0 & 7.65 \\
\hline 100 & 53 & 2.30 & 0.05 & 28 & 6.02 & 0.22 & 74 & 3.3 & 8.32 \\
\hline 200 & 65 & 2.67 & 0.04 & 31 & 6.19 & 0.20 & 76 & 3.6 & 8.94 \\
\hline \multicolumn{10}{|l|}{ Significance } \\
\hline Linear & $* * *$ & $* * *$ & NS & NS & $*$ & $* *$ & $* * *$ & $* * *$ & ** \\
\hline Quadratic & $* * *$ & $* * *$ & NS & NS & $* * *$ & $*$ & $* *$ & $* * *$ & NS \\
\hline
\end{tabular}

Old apical phylloclades exhibiting new growth.

$\mathrm{NS}, *, * *, * * *$ Not significant or significant at $P=0.05,0.01$, or 0.001 , respectively.

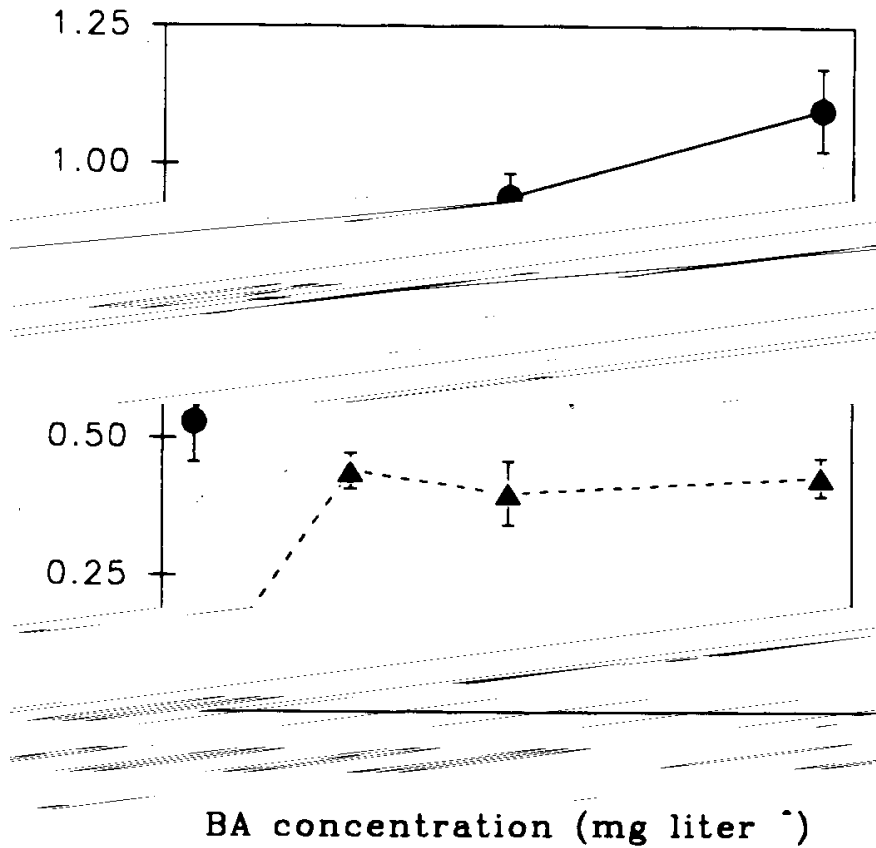

Fig.2. Relationship between BA concentration and phylloclade weight ratio (new phylloclade dry weight/old phylloclade dry weight) for 'Crimson Giant' Easter cactus plants treated at 3 months $(\bullet \bullet)$ or 6 months (A---A) after propagation. Each data point is the mean \pm 1 $\mathrm{SE} ; \mathrm{n}=8$ and 7 for data at 3 and 6 months, respectively.

ported to promote branching in many Cactaceae species (Heins et al., 1981; Ho et al., 1985; Sanderson et al., 1986; Shimomura and Fujikara, 1980; Yonemura, 1979). In the current study, branching was increased by BA at concentrations as low as 10 mg.liter ${ }^{-1}$ (Tables 5 and 6).

Relative to the controls, application of 50, 100, or 200 $\mathrm{mg} \cdot \operatorname{liter}^{-1} \mathrm{BA}$ to 'Crimson Giant' produced $\mathrm{a} \approx 50 \%$ to $400 \%$ increase in dry weight of new phylloclades accompanied by a $\approx 4 \%$ to $30 \%$ decrease in dry weight of old phylloclades (Tables 5 and 6). The effect of BA on dry-matter partitioning between old and new phylloclades is clearly evident from a comparison of the PWR values (Fig. 2). These findings suggest a direct or indirect role of $\mathrm{BA}$ on mobilization of assimilates from old phylloclades to new growth. This hypothesis is consistent with previous research demonstrating the ability of exogenously applied cytokinins to alter translocation patterns of assimilates in intact plants (Quinlan and Weaver, 1969; Tse et al., 1974).
Unit dry weight of new phylloclades on 3-month-old plants decreased linearly in response to increasing BA concentration, whereas the unit dry weight of new phylloclades on 6-monthold plants was not affected by BA (Tables 5 and 6). These differences may be due to the disparity in source size (approximately equal to the number of old phylloclades) between 3and 6-month-old plants. The smaller source may have limited the capacity of the 3-month-old plants to supply assimilates to the additional new phylloclades on BA-treated plants, while at 6 months, the source size was about three times larger and sufficient to supply assimilates to the new growth.

In the Cactaceae, all vegetative and reproductive structures originate from modified axillary buds, i.e., areoles (Gibson and Nobel, 1986). In two-ribbed cacti, such as Rhipsalidopsis and Schlumbergera, areoles that develop below the phylloclade apex are solitary and are dispersed along the phylloclade margin. At the apex, individual areoles are crowded together to form a "composite" areole (Barthlott, 1987). Observations made during the experiments reported here revealed that phylloclades demonstrate a distinct pattern of apical dominance. New phylloclades developed almost invariably from composite areoles and rarely from subapical areoles (data not presented). BAtreated plants produced new phylloclades mainly from composite areoles on apical phylloclades and occasionally from composite areoles on subapical phylloclades, but not from subapical areoles (data not presented). The physiological basis of these dominance relations remains to be elucidated.

Horticultural significance. Most flowers develop on apical phylloclades in Easter cactus (Boyle, 1991; Boyle et al., 1988; Peters and Rünger, 1971). Since BA applications to rooted phylloclades did not affect the number of apical phylloclades at 316 DAP (Table 2), BA would probably have little or no influence on the number of flowers developing on mature plants (with three to five tiers of phylloclades). Hence, application of BA to rooted phylloclades appears to have no horticultural value for production of Easter cactus. In contrast, BA at concentrations from 50 to $200 \mathrm{mg} \cdot$ liter $^{-1}$ was effective in increasing the number of new phylloclades (approximately equal to the number of apical phylloclades) when applied to 3- and 6-month-old plants. The data presented here indicate that BA may be useful for modifying plant architecture of Easter cactus to increase flowering and product marketability.

\section{Literature Cited}

Barthlott, W. 1987. New names in Rhipsalidinae (Cactaceae). Bradleya 5:97-100. 
Boyle, T.H. 1991. Temperature and photoperiodic regulation of flowering in 'Crimson Giant' Easter cactus. J. Amer. Soc. Hort. Sci. 116:618-622.

Boyle, T.H., D.J. Jacques, and D.P. Stimart. 1988. Influence of photoperiod and growth regulators on flowering of Rhipsalidopsis gaertneri. J. Amer. Soc. Hort. Sci. 113:75-78.

Gibson, A.C. and P.S. Nobel. 1986. The cactus primer. Harvard Univ., Cambridge, Mass. p. 163-164.

Gomez, K.A. and A.A. Gomez. 1984. Statistical procedures for agricultural research, 2nd ed. Wiley, New York. p. 187-240, 272315.

Heins, R.D., A.M. Armitage, and W.H. Carlson. 1981. Influence of temperature, water stress, and BA on vegetative and reproductive growth of Schlumbergera truncata. HortScience 16:679-680.

Ho, Y.S., K.C. Sanderson, and J.C. Williams. 1985. Effect of chemicals and photoperiod on the growth and flowering of Thanksgiving cactus. J. Amer. Soc. Hort. Sci. 110:658-662.

Liberty Hyde Bailey Hortorium. 1976. Hortus third: A concise dictionary of plants cultivated in the United States and Canada. Macmillan, New York. p. 947-948.

List, R.J. 1951. Smithsonian meteorological tables, 6th ed. Smithsonian Inst., Washington, D.C. p. 506-512.

Mauseth, J.D. 1976. Cytokinin- and gibberellin acid-induced effects on the structure and metabolism of shoot apical meristems in Opuntia polyacantha (Cactaceae). Amer. J. Bot. 63:1295-1301.

Mauseth, J.D. and W. Halperin. 1975. Hormonal control of organogenesis in Opuntia polyacantha (Cactaceae). Amer. J. Bot. 62:869877.

Milthorpe, F.W. and J. Moorby. 1979. An introduction to crop physiology, 2nd ed. Cambridge Univ., Cambridge, England. p. 111116.
Peters, J. and W. Rünger. 1971. Blütenbildung von Rhipsalidopsis. Gartenbauwissenschaft 36:155-174.

Quinlan, J.D. and R.J. Weaver. 1969. Influence of benzyladenine, leaf darkening, and ringing on movement of ${ }^{14} \mathrm{C}$-labeled assimilates into expanded leaves of Vitis vinifera L. Plant Physiol. 44:12471252.

Rünger, W. 1984. Einfluß von 6-Benzyladenin (BA) bei verschiedenen Temperaturen im Kurztag auf Blütenbildung und vegetatives Wachstum von Schlumbergera. Gartenbauwissenschaft 49:36-39.

Salisbury, F.B. and C.W. Ross. 1978. Plant physiology, 2nd ed. Wadsworth Publ., Belmont, Calif. p. 258-264.

Sanderson, K.C., Y.S. Ho, W.C. Martin, and R.B. Reed. 1986. Effect of photoperiod and growth regulators on growth of three Cactaceae. HortScience 21:1381-1382.

SAS Institute, Inc. 1985. SAS/STAT guide for personal computers. version 6 (ed.). SAS Institute, Cary, N.C.

Shimomura, T. and K. Fujikara. 1980. Stimulation of axillary shoot formation of cuttings of Hylocereus trigonus (Cactaceae) by presoaking in benzyladenine solution. Scientia Hort. 13:289-296.

Tse, A.T.Y., A. Ramina, W.P. Hackett, and R.M. Sachs. 1974. Enhanced inflorescence development in Bougainvillea "San Diego Red" by removal of young leaves and cytokinin treatments. Plant Physiol. 54:404-407.

White, J.W., C. Allen, M. Easley, and P. Strock. 1978. Effects of growth regulants on Opuntia basilaris. HortScience 13:181-182.

Wilkins, H.F. and W. Rünger. 1985, Rhipsalidopsis, p. 178-179. In: A.H. Halevy (ed.). Handbook of flowering. vol. IV. CRC, Boca Raton, Fla.

Yonemura, K. 1979. Studies on the control of flowering in Christmas cactus. Spec. Bul. Aichi-Ken Res. Ctr., Nagakute, Aichi, Japan. 